DOI: 10.2478/RAE-2019-0022 Review of Artistic Education no. 182019 200-211

\title{
6. METHODS OF ACHIEVING STYLISTIC UNITY BETWEEN PORTRAIT, COSTUME, AND THE THEATRE PLAY SPACE
}

\author{
Mihai Cosmin Iațesen ${ }^{177}$
}

\begin{abstract}
Creating stylistic unity within a theatre play is more than just a complex process. The original interpretation of the language forms, specific to each artist that becomes part of this creative act, lies within the final aesthetic product. This article starts by analysing the concept of form and movement as a result of syncretism on various levels, from style and movement, to expression and feelings. To achieve this, the author describes the aesthethics of form emphasising the meaning of stylistic unity in achieving the artistic vision of a show. The paper defines compositional laws and theatrical methods that make the muppet play become a harmonic visual ensemble and stylistic unity. Some of these are: stage props and background; the kinetic criterion of moving forms; the ergonomic criterion of forms in space; the criterion of materiality - in creating the clothing and the costume design.
\end{abstract}

Key words: form, space, portrait, costume, theatre play

\section{Introduction}

Composing the stylistic unity in a theatre play and particularly in animation theatre is a very complex process and is founded on a comprehensive collage of angles: director's conception, scenography vision, the actors' interpretation, music, and the show choreography, as well as the space structure and the adequate stage fitting. The originality in interpreting the language forms, specific to each artist who participates to the creative act, is reflected in the final esthetical product. The value given by synchronising the language elements would characterise the artistic manifestation within a certain style. This is done through particularities that are fundamental to the formation of the same 'wave' that created the arts osmosis.

The art of animation is now considered by some scholars to be a total art, aesthetically characterized by syncretism. This is a fundamental attribute ${ }^{178}$ (Bălăiţă A., 2007, p. 6), that symbolically connects - through ways of expression - to a fantastic world. Animation has become a complex syncretic art, encompassing language elements specific to theatrical art, music, dance, graphics, sculpture, painting and design.

Through synchretism, the art of animation becomes a flagship through the process of stage representation [...] the originality is down to symbiosis of the human-doll binomial with the inert matter and vitality [...] this adding to the creation of another world, born of imagination, myth and play [...] in magical,

\footnotetext{
${ }^{177}$ Lecturer PhD., „George Enescu” National University of Arts from Iasi, Romania, email: iatecos@yahoo.com

${ }^{178}$ Aurelian Bălăiță, Incursion in the animation theatre, Artes, Iași 2007, p.6.
} 
subtle, spontaneous, unexpected ways, in a continuous metamorphosis ${ }^{179}$ (Dănăilă N., 2003, pp. 201-201).

\section{Discussions}

Stage expressiveness becomes impetuous in the transposition of play space. The directorial vision, the puppet animation and technical animation needs depend heavily on scenario approaches and the plastic structure of the elements described or imagined in the scene. The combination of traditional control and movement systems with modern ones, alongside with the modernized techniques and labour technologies orientates us towards useful and favorable transposition of ideas. This is how scenography of the show becomes a harmoneous ensemble of consonant shapes. Scenography is an artistic synthesis, where several arts meet and collaborate to produce a syncretic product, the show $^{180}$ (Truica, 2003, p.100). The compositional and stylistic unity, specific to scenography can favourably be achieved through simultaneous correspondence between language elements and plastic expression.

Besides principles of stylistic unity, specific to the animation theatre, there are many similarities that can be found between the sphere of visual arts and plastic arts. From synthesis of the expression elements going from abstract to concrete and vice versa, to the observance of puppets or marionettes' transpositions to a scale that is adapted to the playing space, we can observe the similarity between style and technique. In addition, ${ }^{181}$, the chromatic harmonization of the portrait with the costume made, the relation between the animated object and the decoration and the chromatic agreements

Amongst scenographic elements are some principles that underlie the stylistic vision. Plastic motives and methods of interpreting natural forms are a means of action. Interpretation of reality, for example, by metamorphosis of phytomorphic, zoomorphic and anthropomorphic structures in the animation theatre is well-known. The costume design and its suitability according to the given scenario is a test for both the director and the stage designer, especially for the actor and tailor of the doll or puppet suit. In the art of the animation show, the character of the puppet theatre is created by a plastician and an actor and his shape is based on a concept that leads to [...] a different kind of message both from the plastic arts and the actor's theatre ${ }^{182}$ (Pepino C., 1998, p. 6).

The stylistic unity between portrait, costume and playing space is one of the many themes of styles and techniques in building puppets and decorations animation theatre. Analyzing the ways in which this content was achieved, I followed the relationship between the portrait of the actor portrait - the portrait of the doll; actor costume - doll costume; the stage space - the game space itself.

\footnotetext{
${ }^{179}$ Natalia Dănăilă, The Magic of the show world, Junimea, Iași, 2003, op. cit. p. 201 - 201.

${ }^{180}$ Ion Truică, Theory of scenography, Junimea, Iași, 2003, op.cit. p.100.

${ }^{181}$ Idem, p.45.

182 Cristian Pepino, Idols and muppets, the magic of a world,Alma, Galați, 1998, op. cit. p. 6.
} 
In a certain scenic setting, the mask's chromaticity will be subordinated as an element of the architectonic form, depending on its size. The décor composed of architectural volumes will create the sensation of diminishing the portrait, the figure of the whole character.

According to the theatrologist Anca-Doina Ciobotaru, the puppet theatre cannot be successfully created without involvement, without shapes, volumes and colors applied to the characters and theatrical spaces through the grace, rhythm and dynamic impulses of music, causing affective states. The sine qua non condition of the animation theatre is the relationship of interdependence between plastic, sound and motion ${ }^{183}$, (Ciobotaru A.D., Iaşi, 2006, p.181). Materiality -in clothing creation and costume design implies stage suitability Such as the frame in the case for a painting, the costume can portray and value the portrait - as a sculptural artistic achievement.

Communication is done on several levels, through specific language, signs and symbols that create a new reality. A reality that outlines through perfect synchronization of speech with the actor's movement and gestures ${ }^{184}$, (Bălăiţă A., 2007, p.37). In the general structure of stylistic unity, the director is determined on the basis of some draft sketches to establish a dominant aspect of the verbal, nonverbal, visual and sound language elements specific to the animated theatre performance ${ }^{185}$ (Ciobotaru AD, 2015, p. 105). A component of the theatrical performance, the scenography itself, isolated from the dramatic opera ensemble, is an almost non-communicable art ${ }^{186}$ (Constantin, 1977, p.126).

The relationship between space, character and text in the scenography of the animation theatre is an important way to control and develop the stylistic unity between portrait, costume and playing space. Non-verbal communication elements can convey similar meanings, but the balance between them may be weak because the message transmitted to the public depends on the means of achieving the expressivity of a doll ${ }^{187}$ (Ciobotaru A.D., 2006, p.64). As with visual arts, the emphasis is on the language expressiveness. The theatrologist Anca - Doina Ciobotaru reiterates these specific means of puppet expressiveness as follows: originality (language customization), power of communication (semantic substance), balance in decor - character - text - music, its shape and functionality) and the room-to-play space ratio.

The predominance of energy impulses characterized by spontaneity, perspicacity and innovation have led to a metaphorical way of communication, often in close correlation with the visual decor and sound decoration or the so-

\footnotetext{
${ }^{183}$ Anca Doina Ciobotaru, Animation theatre between magic and arts Princeps Edit, Iași, 2006, op. cit. p.181

${ }^{184}$ Aurelian Bălăiță, op. cit., p.37.

185 Anca - Doina Ciobotaru, In search of the muppet, Artes, Iași, 2015, p.105.

${ }^{186}$ Paul Constantin, Small enciclopedia of architecture, and applied decorative arts, Științifică și Enciclopedică, Bucharest Științifică și Enciclopedică, Bucharest, 1977, p.126.

${ }^{187}$ Anca Doina Ciobotaru, Animation theatre between magic and art, Princeps Edit, Iași, 2006, p.64.
} 
called audible sound universe ${ }^{188}$ (Bălăiță A., 2007, p.36, 40). The musical component of a show contributes to the achievement of stylistic unity and leads to a memorable reception of the artistic message. Music will always attract and stimulate the visual component of the performance, and its leitmotifs can bring an important rhythm to the play, as it unites and ennobles the other elements of language. The power of imagination will work together with the sound environment, glossing on the avatars of the rhythms given by the actors' impulses and the energy of their creativity.

Through signs, masks, dolls, puppets, symbolic objects, but created by the techniques of plastic art and expressively manifested by the laws of the theatre, the playing space becomes a sui-generis, metamorphosed, personalized medium, conducive to the development of the actions developed in the scenario. This is how practical objects and the use of body language is magic, religious, ludic and profane, all at the same time. The art of animation theatre is characterized by plurivalent expression, namely: visual - epic - playful and dramatic. Thus, at the confluence of plastic arts (graphics, painting and sculpture) with the rhythmic arts (music and dance) we could symbolically identify the symbiosis between epic, lyrical and dramatic arts. Through three types of individuality (that of the creator, of the work and of the overall style), the art of animation becomes autonomous and is under the force of playful dominance ${ }^{189}$, (Bujoreanu-H.R., 2008, p.28-29).

The animated object cannot always be defined as a doll. [...] Through intrigue, dialogue, dramatic situation, text and, above all, the important constituent element - music, animated forms can evolve to genres of animation $\operatorname{art}^{190}$ (Pepino C., 1998, p. 6). Conceived through several theatrical-specific means, the puppet language is based on the transformation of emotional content into expressive forms with different qualities specific to the animation theatre ${ }^{191}$ (Bujoreanu-H.R., 2008, p.31). This involves a whole series of issues, as follows: the directorial vision, the scenographic vision, the actors' interpretation, the music and the choreography of the show and, last but not least, the plastic layout of the space and the proper fitting of the scene. The forms of animation theatre show the style of representation or interpretation.

\section{Results}

In the animation theatre the the key to structuring the images created on the stage by the main character is the actors. These "superheroes", with an unlimited professional dedication, have the ability to adapt to the exigencies imposed by the artistic concept pursued. They can determine the substantial semantic animation of the inert matter from which the decorations, puppets and

\footnotetext{
188 Aurelian Bălăiță,op. cit.7, p.36, 40.

189 Raluca Bujoreanu-Huțanu, The autonomy of the muppet theatre, Artes, Iași, 2008, p.28-29.

${ }^{190}$ Cristian Pepino, Idols and muppets, the magic of a world, Alma, Galați, 1998, op. cit. p. 6.

${ }^{191}$ Raluca Bujoreanu-Huțanu, op. cit., p.31.
} 
the props of a show are built. Through their ability and intervention, with the language specific to the animation theatre, the actors become the main vectors in transmitting the message to the receiving audience. They are alive, just like the puppets they animate and interact with or relate directly to. Their art - the art of animation is a living art $^{192}$ (Ciobotaru A.D., 2006, p.11).

Along with the symbols, the metaphors, and the sensitivity characteristic to the human nature with which they were endowed, they can reveal to the world the mystery of the message. Theatre is known and understood to be the art of a natural and unopened expression of inner anxieties, specific to the human spirit. This art combines feelings, has a temporary character and defines the artistic act, which happens "here" and "now". The divine moment in which the affective moment is lifted to the maximum of living in the room's receiver must be carefully constructed in a show. As the theatre of animation reveals to the receiver the plastic images that represent a reality suggested by symbols and signs, referring to everyday life, the interpretation of reality data through means of expression of ideas, the total artistic act will generate attitudes of opinion in society.

The constructivist structuring of form within space has required transdisciplinary technological advancements, for artists to explore new expressions in the sphere of the tri-dimensional. The remarkable importance of sculpture in the renewal of the means of expression in the 20th century is associated with multiple possibilities of expression related to the metamorphosis of the form, which was undoubtedly the result of the progress of science and technology.

In the last century, visual arts, set out to overcome nothingness and actually to defeat ... the time. The process of rapid transformation of society corresponds at the artistic level to the intuitive evolution of the metamorphosis of the appearance that will form in the future. Scenic image construction styles are an important part of the process of harmonizing and subordinating details to the overall idea being pursued. As the elements of architecture, furniture and clothing are chosen more harmoniously, the performance has an obvious or allusive style ${ }^{193}$ (Truica, 2003, p. 46)

In the plastic construction of puppets and decoration for the animation theatre, it is necessary to take into account the importance given by the purpose and functionality of the objects, as well as the dimensions, the mass, the articulation and the other characteristic properties presented by the materials from which they are made. The observation that the best decoration is the one without autonomic significance ${ }^{194}$ (Constantin, 1977, p.126), has a logical foundation, according to which the ideological content of the decoration structure is based on the subordination relation between the theatrical ways and

\footnotetext{
${ }_{192}$ Anca Doina Ciobotaru, Teatrul de animație între magie și artă, Editura Princeps Edit, Iași, 2006, p.11.

${ }^{193}$ Ion Truică, Theory of scenography, Junimea, Iași, 2003, op. cit. p.46.

${ }^{194}$ Paul Constantin, Small enciclopedia of architecture, and applied decorative arts, Științifică și Enciclopedică, Bucharest, 1977, p.126.
} 
means of expression. It is good to know from the very beginning whether a particular material will fully serve the purpose we pursue in the process of artistic metamorphosis of forms in the stage space. The new approaches of theatre have led to expressive scenic movements with memorable innovations. For example, at the Meiningen theatre ${ }^{195}$ (1870-1890), two-dimensional painted decors have been replaced with those built with a three-dimensional character ${ }^{196}$ (Constantin, 1977, p.127).

The scenographic orientations at the beginning of the 20th century were more inclined towards the scenic convention. The suggestion, symbol, simplification, and focus of expressions have remained active, accepted as keys to interpretation. The tendency has increasingly focused on an autonomous theatrical synthesis, created and governed by the director. Gradually, with the passage of time, the directors realized that theatre needed plasticians, innovative ideas, and ultimately the results of their 'mutilation'. The form, created and adapted by the scenographers on the basis of the directed content, has different stylistic valences from case to case. [...] The choice of the means of scenic transposition is an important stage, as it will determine both the stylistic unity of the show and the communicative level to be established between the stage and the hall ${ }^{197}$ (Ciobotaru A.D., 2006, p.63).

Depending on the directorial ideas, the construction of the scenic image is often based on the archtypal schemes of simplified compositions in wellestablished settings. Some objects may be subject to later modifications to elementary sketches. For the purpose of their their harmonization both functionally and chromatically, the properties of the materials and the characteristics of the surfaces (large, small, light or matte to glossy) are observed and exploited. This osmosis of specific elements of language fills in the incorporation of forms into performances that produce an intense intuitive memory. The compositional and plastic principles that lines, shapes and colors can acquire by metamorphosis through fundamental schemes in the play of the doll, leads to a better decipherment and suggestion of the identity of characters, space and the psychological phases through which they evolve.

Synchronization of the props with the stage space in the animation show lead to a better adaptation of the puppet play to the proposed scenic context. Through attitude, posture, movement of the body of the actor and that of the puppet and gesture, expressional relations are always built, resulting in a proper and efficient combination of the elements of language. The characteristics of the puppet style, for example, are distinguished by the fact that they combine the following aspects: the construction and the functional structures with the

\footnotetext{
${ }^{195}$ Teatru fondat de către Ducele Georg al II -lea de Saxa - Meiningen, mecena, regizor și scenograf pasionat, în care s-au făcut primele montări moderne cu figurație foarte numeroasă, manevrată în mișcări scenice expresive și unde s-au făcut primele montări moderne cu figurație foarte numeroasă.

${ }^{196}$ Paul Constantin, Small enciclopedia of architecture, and applied decorative arts, Științifică și Enciclopedică, Bucharest, Științifică și Enciclopedică, București, 1977, p.127.

${ }^{197}$ Anca Doina Ciobotaru, Animation theatre between magic and art, Princeps Edit, Iași, 2006, p.63.
} 
aesthetic of the plastic shape; involves the means of expression specific to the plastic arts, architecture and design in scenography, to which, in addition, choreography and music are added; animating puppets/ symbolic objects, using various systems; is based on ancient rituals - the premise of the customs and traditions of different social groups, realizing a syncretic cultural synthesis; time and space, feelings, emotions and animation rituals; respecting human typologies and life concepts; including a magical, playful and profane character; reaching a metaphorical character with new language horizons in interpreting the form.

In his Some Considerations about puppet theatre Serghei Obrazov argues that 'The Puppet' is the symbolic expression of man [...] having the power to generalize reality and [...] always remaining a reflex of man's need for charm and poetry ${ }^{198}$, From a material point of view - a miniature of canvas and cardboard, in the puppet animation theatre, the instrument becomes the archetypal sign of profound wisdom and poetic symbol of expression through a language with unique, original features. If we look at the doll as a metaphorical object then we can accept that it is defined by materiality, functionality and significance $^{199}$, (Ciobotaru A.D., 2006, p.224).

The puppet but moreover - the mask - involves good knowledge of the plastic portrait. The general aesthetic features of the puppet refer to a man's reflex for charm and poetry, considered lyrical-dramatic. It rejuvenates with the renewal of emotions and it is a supernatural being, not a representation of a real character. In the animation theatre [...] the traditional, classical line coincides naturally with the innovative experiment, with the bold exploitation of some new formulas $^{200}$ (Margareta Niculescu, 1966, p.5). The mask concept, from archetype, to medium and process, as a puppet language element has become a form of manifestation, a pre-artistic communication ${ }^{201}$ (Bujoreanu-H.R., 2008, p.53). The mask has become important in the animation theatre because it involves a real foundation on the portrait with its simplified or enhanced features.

The portrait is a very important study theme not only for painters or sculptors, but also for those who have chosen to become puppeteers. Whether these artists want to build a doll or a puppet, the knowledge of internal and external anatomical structures and the rendering of physiognomal peculiarities will provide during the show the familiarization of the public with the aspects of states or appearances. By synthesizing the characters' personality data, each type of doll or puppet can be assigned a particular animation system. If we look closely at the types of dolls, we will always find that throughout the history of mankind, forms of expression have diversified. [...] Depending on the animation

\footnotetext{
198 Margareta Niculescu, Teatrul de păpuși în lume, Editura Meridiane, București, 1966, op. cit.p.5.

199 Anca Doina Ciobotaru, Animation theatre between magic and art Princeps Edit, Iași, 2006, op.cit.p.224.

${ }^{200}$ Margareta Niculescu, Teatrul de păpuși în lume, Editura Meridiane, București, 1966, op. cit. p. 5.

${ }^{201}$ Raluca Bujoreanu-Huțanu, The autonomy of the muppet theatre, Artes, Iași, 2008, p.53.
} 
system, the manifestations were called shadow shows, bunraku puppet shows, hand puppet shows, marionette shows ${ }^{202}$ (Bujoreanu-H.R., 2008, p.66-67).

Making the puppets' costume is an integral part of the conception of the puppet's construction and assembling. The costume is an important component in the context of achieving stylistic unity. The costume - as a visual element highlights a character and completes the character palette. As sculpture can only be carved in wood or in stone or cast in bronze, and painting comes into being in color, in the field of the costume the coat makes man, as the popular wisdom has noted ${ }^{203}$ (Nanu, 2007, p.12). The actor is the living element in the show, but with the actor's disappearance, the costumes will survive only through the care of the stage designers or fashion designers like Doina Levintza. To gain a convincing example of the relationship between actor and costume, the mask game becomes as an ancient landmark element in the animation theatre.

The proportionality criterion and the placement in the stage space of props and decorations, puppets, which are part of the screenplay, are very important for the realization of scenography paintings. Corroborated, they meet the requirements imposed by the visual harmony and the visual ensemble and represent a part of the similarities dictated by the compositional laws, specific to the tri-dimensional space. There are open animation systems and closed systems. Each animation system, specific to the animator's temper, corresponds to a certain type of game space (conventional or unconventional).

According to the dictionary, the term style has several meanings. The philosopher and esthetician Nelson Goodman said that "style arrives when the moment stops, and the feeling begins." In the field of creation, expression of expression is limited to form, manner or method and the stylistics of the animation theatre is closely related to the representation of the animation theatre $^{204}$ (Bujoreanu-H.R., 2008, p.31). The essence of style is closely related to expressing the emotional aspects of the work of art through its form and content, implying the merits of expressing feelings. In the plastic arts style is the perfect expression of the form based on a personal or collective aesthetic ideal and is identified by the unitary artistic expression of a particular epoch or creations viewed as a whole. At a nation's level, style becomes national. (Şuşală, Barbulescu, 1993, p.253-254.).

The puppet's style is characterized by its complexity and combines the functional aspect with the aesthetic of the plastic by making original pictures. Style in the art of animation involves the means of expression specific to the plastic arts, architecture and design in the scenography, to which choreography and music are added. The principles on which the animation is based consists of: animating puppets, or symbolic objects using various systems; this is based on ancient rituals - the premise of the customs and traditions of different groups of

\footnotetext{
202 Raluca Bujoreanu-Huțanu, op. cit. p.66-67.

${ }^{203}$ Adina Nanu, Arts, Style and Costume, Noi Media Print, Bucharest, 2007, op.cit.p.12.

${ }^{204}$ Raluca Bujoreanu-Huțanu, op. cit., p.31.
} 
society, making a syncretic cultural synthesis; spatial-temporal coordinates, feelings, emotions and animation rituals; reporting to human typologies and life concepts; to the magic, ludic and profane character of the animated object. Space is the medium of materialization of the form through expression of creative and artistic thinking. This coordinate can also be perceived as a real or virtual confluence of all forms with originality and value conferred by form and content. Space can be defined as an entity resulting from the subjective reflection of the external world, conditioned and limited by organs of anatomical-physiological sense.

The scenic space is the game space itself, the place where the visual arts, projections, sound techniques and ecclesiastics meet ${ }^{205}$ (Ciobotaru A.D., 2015, p.85). It may also be an unconventional space, but with limited theatrical representation possibilities. Playing space, from an artistic point of view, is included in the layout of the scenic or unconventional space and it represents the framework of actions and conflicts between the characters. Scene space can also be understood as a transit space between two worlds and different degrees of perception and interpretation of the artistic form. The space captures those manifestations of inaccessible life and evolves into the sphere of the concept of living space in close correlation with the living time of the present and the human body of the actor ${ }^{206}$ (Appia, 2000, p. 68-70).

Among the aesthetic evaluation criteria taken into consideration in achieving the stylistic unity are: the proportions - the framing within the limits of the scenic space; consistency / lack of mass - heavy / light (visual sensation); compositional rhythm - repetition and alternation; inner shape tension (concave convex / hollow - full); chromatic contrasts and shapes in space; material texture; surface finishing - structure; structuring the scenic space - modulation; harmony of the ensemble - the balance; originality of plastic design authenticity; subjectivity - relativism. Multicultural personality recognized in many areas since the early 20th century, Matila C. Ghyka was the adept and promoter of the theories that ardently support the relationship between science and art. His overall cultural vision was based on the concept of symmetry. The outstanding personality in the theoretical, mathematical, physical and philosophical sphere, with a transdisciplinary vision, academician Basarab Nicolescu observed in Matila C. Ghyka the presence of an esoteric fascination and numerology, namely the number of golden or divine sections, the golden section or the proportion of gold ${ }^{207}$ (Matila C. Ghika, 2016, p. 11). This point of view emphasizes the harmony of the organic world and the connection of art

\footnotetext{
205 Anca - Doina Ciobotaru, In search of the muppet, Artes, Iași, 2015, p.85.

206 Adolphe Appia, The alive masterpiece, trad. E. D. Popescu, Ed. UNITEXT (UNITER), Bucharest, 2000, p.68-70.

207 Matila C. Ghika, The golden number, pitagoreic rythms and rituals in the development of the Western civilisation, Nemira, 2016, p.11.
} 
with the optimal proportions of the human body, proportions that are necessary for the construction of each muppet.

By applying the principles of contrasts, it is possible to ensure good visibility of the props and decoration in the scenic frame. The chromatic contrasts used in the visual arts to develop shapes, colors and volumes in the plastic space represent a series of important methods for an adequate match of the plastic image. The contrast of colors; warm - cold contrast; closed contrast open; clear - obscure contrast; quantitative contrast; qualitative contrast; contrast complementarity; contrast simultaneously; successive contrast; the contrast of the form itself and in space can be applied brilliantly and by structuring the elements of a stage design in the animation theatre.

The metamorphosis of stage space elements, specific to the 20th century experiments, has become a way of achieving the stylistic unity often found in puppet and puppet theatre. In order to achieve a good stylistic association between these major constitutive elements belonging to important artistic domains, we can refer to the following methods: proportional structure - unit / whole, anatomical fragment / whole figure; stylization (the plastic elements that make up the paintings); synthesis / essentialization of shapes by geometry / stylization; modulation of compositional elements of the assembly; plastic metamorphosis - through deformation, styling, metaphor and allegory; anthropomorphism - personification / attribution of human traits; chromatic agreement (harmonizing the whole with appropriate colors and shades, both for puppets, puppets and objects); eclear (light design, controlled filtration and control, intensity and contrasts of the light-shadow ratio); adaptation of movement systems - manipulation in the play space bounded or mediated by decors, props / type of puppet or puppet; the use of various techniques and materials appropriate to the puppet movement's needs, which can also solve technical problems.

The props and the decoration need to be designed in the scenography workshop according to the rigors of the perspective, the consistency of the mass, and ultimately, they are received through the expression of the sculpturality they are claiming. Perspective criterion - scene rapport, background, and escape points; the kinetic criterion of reporting forms between dynamic and static; the ergonomic criterion of forms in space; the criterion of materiality - in the clothing creation and in the fabrication of the costume. Corroborated, the criteria of stylistic unity meet the requirements imposed by the harmony of the visual scenic ensemble and represent a part of the similarities dictated by the compositional laws, specific to the game space.

The proportionality criterion and the placement in the stage space of props and decorations, puppets or puppets that are part of the script are very important for making scenes of a scenography, as the characters are usually puppets and not actors ... and scenography for the theatre of animation is subject to distinct 
laws, some different from those of the drama theatre ${ }^{208}$, (Bălăiţă A., 2007, p.38). Props and decoration need to be conceived according to the rigors of the perspective, the consistency of the mass; perspective criterion - reporting to scene, background, and escape points; the kinetic criterion of reporting forms between dynamic and static character; the ergonomic criterion of forms in space; the criterion of brightness.

Thus, according to the directorial concept, with the directed artificial light, effects obtained with reflectors and other lighting objects, with traditional energy sources - the candle, the lamp, the lamp or the lantern, lead to expressive - plastic connotations. The correct alignment between portrait, costume and playing space can also be adjusted by the intensity and direction of the lights. Projection elements of the lights in the animation show are also important scenic means to give intensity and chromaticity to the expressiveness of the ensemble. The compositional function of light has the decisive value of synthesising imagery and therefore the message, in the eyes of the public.

\section{Conclusions}

As we will observe in the detailed observations presented below, the scenographic vision of a show is not an easy matter to solve ${ }^{209}$, (Truice, 2003, p. 45). Among the general ways of realizing the stylistic unity in a theatre performance, one can consider: the revelation of some parts of the composition of the elements of the scenic language; accents on shape, color, texture or volume; highlighting the center of interest in each of the scenes or frames of the action; the loss of shadow characters to get out of the discreet scene; the suggestion with an intensified intensity of dramatic conflicts (ie. Caravaggio's painting); rendering the depth of scenic space through a succession of action plans; more easily suggesting different compositional effects: heavy-light, highlow, hollow, thanks to the technical innovations that have also entered this field of visual arts (both the intensity and mobility of the reflectors and of the systems support and manipulation of props and decorations). These norms represent an integral part of the similarities dictated by the laws of composition, and ultimately lead to the realization of the gestural expressiveness and implicitly to the stylistic unity in the playing space.

The attribution of human traits to animated objects, alongside with the proportionality criteria and the placement in the stage space of the props or decor are an important norm. For puppets that are part of the script, these considerations should also be respected. The elements that make up the scenography of a show are identified in the stage space as objects with metaphorical valences. Their forms represent the results of the plastic metamorphosis process in the scenic layout of the images.

\footnotetext{
208 Aurelian Bălăiță, op. cit. p.38.

209 Ion Truică, Theory of scenography, Editura Junimea, Iași, 2003, op.cit. p.45.
} 
Thus, composing the unitary stylistic space in animation theatre, through a process of synchretism and association of forms and methods engaging functional and aesthethic principles, constructively harmonises the plastic visions, making scenography a memorable artistic experience.

\section{References}

1. Appia, Adolphe, (2000), The alive masterpiece UNITEXT (UNITER), Bucharest.

2. Bălăiță, Aurelian, (2007), Incursion in the animation theatre, Artes, Bucharest.

3. Bujoreanu-Huțanu, Raluca, (2008), The autonomy of the muppet theatre, Artes, Iasi.

4. Ciobotaru, Anca - Doina (2006), Animation theatre between magic and art, Princeps Edit, Iași.

5. Ciobotaru, Anca - Doina, (2015), In search of the Puppet, Artes, Iași.

6. Constantin, Paul, (1977), Small enciclopedia of architecture, applied decorative arts, Științifică și Enciclopedică, Bucharest.

7. Dănăilă, N. (2003). The Magic of the show world, Junimea, Iași.

8. Ghika, Matila C., (2016), The Golden number, Pitagoreic Rythms and rituals in the development of the western civilisation, Nemira, Bucharest.

9. Nanu, Adina, (2007), Arts, Style and Costume, Noi Media Print, Bucharest. 10. Niculescu, Margareta, (1966), Muppet theatre around the world, Meridiane, Bucharest.

11. Pepino, Cristian, (1998), Idols and Muppets - the magic of a world, Alma, Galați.

12. Truică, Ion, (2003), Theory of scenography, Junimea, Iasi. 